IJEBR

20,2

98

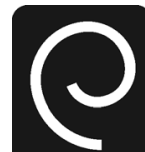

Emerald

International Journal of Entrepreneurial Behaviour \& Research

Vol. 20 No. 2, 2014

pp. $98-107$

(C) Emerald Group Publishing Limited 1355-2554

DOI 10.1108/IJEBR-02-2014-0031

\section{Emancipation and/or oppression? Conceptualizing dimensions of criticality in entrepreneurship studies}

\author{
Karen Verduijn \\ Department of Management \& Organization, VU University, \\ Amsterdam, The Netherlands \\ Pascal Dey \\ University of St Gallen, St Gallen, Switzerland \\ Deirdre Tedmanson \\ Social Work and Social Policy, University of South Australia, \\ Magill, Australia, and \\ Caroline Essers \\ VU University, Amsterdam, The Netherlands and \\ Nijmegen School of Management, \\ Radboud University of Nijmegen, Nijmegen, The Netherlands
}

\begin{abstract}
Purpose - The purpose of this paper is to use the attribute "critical" as a sensitizing concept to emphasize entrepreneurship's role in overcoming extant relations of exploitation, domination and oppression. It builds on the premise that entrepreneurship not only brings about new firms, products and services but also new openings for more liberating forms of individual and collective existence. Design/methodology/approach - Honing in on Calas et al.'s (2009) seminal piece on critical entrepreneurship studies, and building on Laclau's (1996) conceptualization of emancipation as intimately related to oppression, the paper explores different interpretations of emancipation and discuss these from a critical understanding of entrepreneurship. The paper then employs these interpretations to introduce and "classify" the five articles in this special issue.

Findings - The editorial charts four interpretations of emancipation along two axes (utopiandystopian and heterotopian-paratopian), and relates these to various strands of critical entrepreneurship research. United by a general commitment to positive change, each interpretation champions a different take on what might comprise the emancipatory or oppressive potential of entrepreneurship.

Originality/value - As the emancipatory aspect of entrepreneurship has attracted increasing attention among entrepreneurship researchers, the paper formulates a tentative framework for furthering views on the emancipatory aspects of entrepreneurship as a positive phenomenon in critical research - which to date has tended to be preoccupied with the "dark side" of entrepreneurship.
\end{abstract}

Keywords Critical entrepreneurship studies, Emancipation, The dark side of entrepreneurship Paper type General review

\section{Introduction}

In discussing what makes for a "critical" perspective Parker and Thomas (2011, p. 422) astutely point out that "what counts as critical depends on what counts as dominant". Transposing this concept to entrepreneurship studies, we can see that this field has been dominated by those primarily interested in entrepreneurship as a purely market-based and individualist phenomenon: a "special" trait or set of behaviours 
which drive venture creation. This focus on entrepreneurship as a "desirable" economic activity, perceived unquestioningly as positive, "obscures important questions: of identity, phenomenology, ideology and relations of power" (Tedmanson et al., 2012, p. 532). However, if economic value creation was entrepreneurship's only dimension, then there would probably be no need to focus on it as the economy already forms a crucial part of our social imagination. Viewing entrepreneurship solely as a desirable economic activity ignores the many different dimensions of entrepreneurship and in particular many negative effects related to entrepreneurship. One aspect of critical consideration should therefore be to continually highlight and challenge the overly positive image of entrepreneurship. We believe that to date the critical community has been relatively successful in pinpointing the "dark side" of the entrepreneurship phenomenon. Armstrong (2005), for example, has exposed the ideological nature and convenient political manipulation of many contemporary applications of the rhetoric of entrepreneurship in the context of neo-liberal ideology. Jones and Spicer (2009) have deconstructed the accepted norms in diverse representations of entrepreneurship to reveal what is both cynical and also sinister behind the "smiling mask". Likewise, authors like Ahl (2004), Pio (2005), Essers and Benschop (2007, 2009), Essers (2009), Essers et al. (2010) and Ozkazanc-Pan (2009) among many others have sought to "voice" other entrepreneurial subjectivities than those traditionally privileged. The symbolism of "the entrepreneur" based on essentialist conceptualizations of the archetypical "white" (European) male is also being increasingly challenged. In this vein, influential contributions can be traced which stem from feminist theorizing which has inter alia disclosed the gendered nature of entrepreneurship by showing how sexbased differences are perpetually reproduced in academic articles, media reports and entrepreneurial practice, thus contributing to women's subordination (Ahl, 2004, 2006). Feminist research has reintroduced a sense of agency into the understanding of enterprise as gendered discourse, by pinpointing how women variously resist male-dominated discourses through complex struggles over meaning (Essers and Benschop, 2007). More recently, postcolonial feminist perspectives have shown how westernized images of "Otherness" impact on the legitimacy and agency of Muslim female entrepreneurs (Essers and Tedmanson, 2014). Critical research has been instrumental for creating insights into how entrepreneurship works as an ideological support of capitalist hegemony (Costa and Saraiva, 2012). Arguably one of the greatest contributions of critical understandings of entrepreneurship up to this point is the revelation that entrepreneurship does not necessarily offer a solution to crisis, such as the current recession, but that it is structurally linked with the emergence of crisis (Jones and Murtola, 2012a).

Generally, a critical perspective can help unveil, disclose or realize what is often buried beneath or contained within the more "taken for granted" assumptions underpinning entrepreneurship studies and in doing so can be a positive and liberating force that revitalizes, repositions and reconceptualizes what might otherwise seem paradoxical. It is the messiness and unpredictability of entrepreneuring that attracts critical scholars; and it is in addressing the ambivalence and contradictory tensions inherent in entrepreneurship that critical scholars can make a contribution. This essay particularly explores one contradiction inherent in entrepreneurship: its oppressive/ destructive vs its emancipatory potential. On the basis of Laclau's (1996) understanding of emancipation, which stresses the co-implication of emancipation and oppression, we explore four different interpretations of emancipation, along two axes (utopian-dystopian and heterotopian-paratopian). Each is illustrated by means of reference to extant
Emancipation and/or oppression?

99 
IJEBR

20,2

100 contributions. We conclude with an introduction to the individual articles of this special issue and relate them back to our tentative framework.

\section{The emancipatory potential of entrepreneurship}

Critical approaches quite generally entail a positive outlook as they are geared towards emancipation, that is, towards liberating "human beings from the circumstances that enslave them" (Horkheimer, 1982, p. 244). Consequently, most critical research tries to offer a basis for increasing freedom in all its forms. This is precisely what Rindova et al. (2009) have tried to do when seeking "to broaden the focus of entrepreneurship research by drawing attention to the emancipatory aspects of entrepreneuring" (p. 478). Instead of conceiving "entrepreneuring" narrowly as the creation of new ventures and the pursuit of profitable opportunities, the authors define the terms as "efforts to bring about new economic, social, institutional, and cultural environments through the actions of an individual or group of individuals" (p. 477). In this way, Rindova et al. set the tone for conceptualizing entrepreneurship as an inherently emancipatory activity, while offering valuable insights with regard to the emancipatory agendas inherent in many entrepreneurial endeavours (and not just those with a public reputation as change agents).

Against this, Verduyn and Essers (2013) argue that entrepreneurship is at times romanticized in the way it is construed as a "Holy Grail" of elevation and emancipation. They illustrate how attempts at transforming a particular "category" of people (i.e. ethnic minority women of Turkish and Moroccan descent in the Netherlands) into proper entrepreneurs may in fact be far less liberating than what one might assume. The question that lingers in the opposition between Rindova et al. and Verduyn and Essers is whether entrepreneurship is emancipatory or not. We believe that a productive way to address this question is to let go of an "either-or" contested position, and instead endorse an "as-well-as" position which essentially contends that emancipation and oppression are both immanent potentials of entrepreneurship. Drawing inspiration from Laclau's (1996) elaboration of emancipation, we conceive of entrepreneurship as a two-headed phenomenon, comprizing emancipation and oppression as forces which stand in a relationship of constant tension. As Laclau (1996) makes clear: "there is no emancipation without oppression, and there is no oppression without the presence of something which is impeded in its free development by oppressive forces" (p. 1). Laclau's dualistic schema helps us understand that the "dark side" of entrepreneurship represents the flipside of emancipation or entrepreneurship's oppressive counterpart. More succinctly, emancipation represents the "moment" in Laclau's terminology, which liberates that which precedes the "liberating act" (read oppression). Laclau's dualism - which is best thought of as a continuum and not as a polarity - permits us to envision entrepreneurship as always tending either towards emancipation or towards oppression. It is important to note here also that "emancipation" and "oppression" lend themselves to quite different interpretations, notably with regards to their scale or scope. If we turn towards Laclau, we can see that emancipation is delineated in universal terms, represented as the eradication of oppression in all of its forms. In so far as emancipation projects a future reality which is superior (i.e. more just, equitable, safe, etc.) compared to the current situation, it is utopian at its core. Laclau's understanding of emancipation draws from a utopian vision of a better world (Jameson, 2005), a view particularly prevalent in the critical theory of the Frankfurt School. So conceived, utopia appeals to more macro-oriented forms of emancipation that tend to "draw our attention to those acts that seek to fundamentally challenge broader social structural modes of domination" 
(Huault et al., 2014, p. 42). Alternatively, utopia might be conceived, not as a desired state where realization is deferred into the future, but as actually existing places of difference and alterity. We prefer to speak here of heterotopias (Foucault, 1986) which alludes to existing places and practices that variously provoke and appropriate the existing order. A heterotopian view focuses on micro-manifestations of emancipation as epitomized by entrepreneurship's engagement in localized, everyday struggles and practices of freedom. Having distinguished micro- and macro-manifestations of emancipation based on the concepts of utopia and heterotopia, a similar distinction can be drawn with regard to oppression. The more macro-oriented and systemic manifestation of oppression is dystopia, which emphasizes entrepreneurship's relation or co-implication with totalizing systems of domination, exploitation and control. Paratopia in turn represents the negative equivalent of heterotopia, and conceives of oppression as fleeting, often spontaneous and even unintended, misconducts and aberrations of entrepreneurship and entrepreneurs. Taken together, we have at our disposal the two axes - utopian-dystopian and heterotopian-paratopian - which can be interwoven in the form of the following grid (cf. Figure 1).

Though it might be impossible to draw a hard line between the four forms presented in Figure 1, and although we concede also that many critical contributions will likely be a mix between the four forms, we believe it is conceptually valuable to distinguish macro-accounts - of utopian and dystopian interpretations of entrepreneurship from micro-accounts - or heterotopian vs paratopian views of entrepreneurship.

\section{A utopian view}

A utopian view of emancipation can be traced back to critical theory as developed by the Frankfurt School which postulates emancipation as the act of liberating "human beings from the circumstances that enslave them" (Horkheimer, 1982, p. 244). A utopian view of entrepreneurship comprises a focus on how entrepreneurship addresses larger social structural challenges (Huault et al., 2014). The emphasis might be placed here on normative evaluations (cf. business ethics literature) which define principles of emancipatory forms of entrepreneurship. Also, utopian approaches might contain approaches which relate entrepreneurship to a different, more just and equitable form of capitalist economy. Examples include those contributions stipulating entrepreneurship as a societal force for the alleviation of poverty, and the creation of

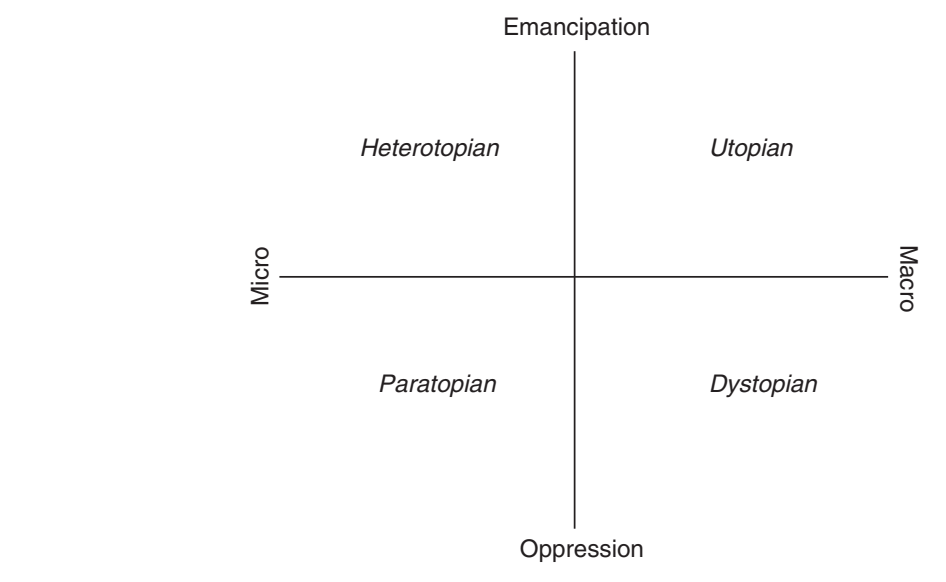

Emancipation and/or oppression?

101

Figure 1.

A grid portraying different dimensions of criticality 
IJEBR

20,2

102 wealth and well-being (Sarasvathy and Venkataraman, 2011). Another example is Harvard's Michael Porter, who, in an attempt to rethink how modern capitalism should ideally work, reverts to social entrepreneurship as one way to conceive of a better kind of economy (i.e. one based on his shared value proposition) being established (Driver, 2012). The utopian view is premised on the idea that it would be possible, albeit not easy, to create the conditions under which people can live freely, - uninterrupted by oppressive relations of power. Yet, not everyone might agree that such a universal "breaking free" is at all possible or that a space of autonomy for everyone (within capitalism) is attainable. Many are sceptical about the utopian prospect of emancipation as expressed by the Frankfurt School.

\section{A heterotopian view}

Unlike utopias, which may prove to be too utopian (i.e. "idealizable but not realizable", Levitas, 2013), heterotopias are places of difference and alterity which often exist at the margins of or in (partial) opposition to the mainstream. Taking this view, the focus is on the mundane practices through which entrepreneurs create various, local conditions of empowerment, liberation and alternative identity politics (hence "hetero-topia"). A heterotopian view is interested in existing counter-sites, which are effectively enacted utopias. Heterotopian perspectives of entrepreneurship privilege localized struggles through critical attention to ongoing resistance/s to the minutiae of oppression - they privilege (micro) empowering moves. Heterotopian inquiries (Hjorth, 2005 ) tend to describe actually existing spaces and practices which invite alternative modes of being at a local level (Spicer et al., 2009). Examples include the stories of female entrepreneurs who resist male-dominated subject positions, and who become active agents against the hegemonic entrepreneurship (e.g. Essers and Benschop, 2007, 2009); and studies which take into account micro-sociological practices and processes as well as biographical experiences in the establishment of emancipatory endeavours (Goss et al., 2011).

\section{A dystopian view}

The dystopian perspective represents the counter-model to the utopian perspective, construing entrepreneurship as systematically related to the establishment of oppressive symbolic and material realities. The focus here is on how entrepreneurship consistently and pervasively prevents emancipation taking place. Potential perspectives include ideology critique, discourse theory and studies which draw on political economy. Illustrations include those contributions which portray entrepreneurs as inherently egotistical, selfish, wayward, dominant and opportunistic individuals (DeLeon, 1996); contributions portraying entrepreneurship as an ideological discourse which deadens our critical faculties (Costa and Saraiva, 2012); and contributions disclosing the surplus value of entrepreneurship which is reinvested only to the benefit of the capitalist entrepreneur (Jones and Murtola, 2012b). Above all, a dystopian view sheds light on how the discourse of entrepreneurship lends ideological support to a view of the capitalist economy as the single best way of producing wealth and value in society (James, 2008). At the same time, the dystopian view points out that the dark side is part of entrepreneurship's normal functioning (Spicer, 2012). By showing how entrepreneurship is systematically linked to environmental pollution, bribery and corruption and/or human exploitation, a dystopian view sheds light on why, despite the ever more visible predicament of entrepreneurship, dominant accounts try to suppress analyses of and discussion about entrepreneurship's underside. 


\section{A paratopian view}

Paratopia is suggested as the more micro equivalent of dystopia. This perspective sees entrepreneurship as leaning towards oppression, where oppression is conceptualized as the petty misbehaviours or negative, unsystematic and at times unintended side effects of entrepreneurial practice. Entrepreneurial activities are viewed in this way as not necessarily positive and/or contributing to the very problems such activities might be trying to eliminate. An example here is micro-finance which is introduced as an entrepreneurial solution to poverty but which can have various negative ramifications ranging from domestic violence, to the stigmatization of failed (indebted) entrepreneurs (Calas et al., 2009). Another example is how the white, male, western entrepreneurship archetype which is being taken for granted - and hence imposed by official organizations - affects female migrant entrepreneurs (Verduyn and Essers, 2013).

The papers in this Special Issue each make an important contribution, to the thematic of the emancipatory potentialities of entrepreneurship and the dimensions of criticality we have conceptualized. Each explores an under-discussed, problematic and fascinating aspect of entrepreneurial effort, and each is notable for the attention the authors give to context, and to relations of power, oppression and meaning making in the different enterprizing worlds being covered. In the next section we present the five articles in this Special Issue.

\section{Presentation of contributions to this Special Issue}

The first contribution, by Bruni and Perrotta, explores how gender stereotypes and practices are at work in positioning "Him" and "Her" in the (same) firm, and thus problematizes the rhetoric positing of entrepreneuring as an individual or isolated activity. The authors have conducted an empirical study in the context of artisan activity, a sector of particular interest because of its usual solistic and "male-centred" nature. The analysis provided by Bruni and Perrotta is based on 18 verbal histories, and concentrates on the discursive positioning of the interviewees, as men and women, and as entrepreneurs. The analysis discloses two main story types: stories of subsidiarity on the one hand (where one of the partners "marries an artisan" and consequently assists with the work of the other), vs stories of complementarity on the other hand (where the partners are more mutually involved). The division is not a strict one, for the stories that are being grouped show significant variation which helps nuance the analysis. Likewise, there are different emancipatory effects. The stories of subsidiarity tend to follow a more traditional gendered division of (work) relations, while the stories of complementarity point to the active construction of the subjects by themselves as entrepreneuring women and men. Here, being a male or female entrepreneur is being negotiated in the process, it is something "a posteriori" rather than "a priori", as Bruni and Perrotta assert. Bruni and Perrotta's study, with its focus on "the contextual dynamics in which entrepreneurial activity acquires meaning for specific people, in specific places, and for situated logics which may differ from those normatively presumed" (p. 108) can be "classified" as an exemplar of the heterotopian view elaborated above. It is a most interesting and nuanced account of how male and female partners negotiate their roles when "entrepreneuring together", and it shows the importance of considering "mixed situations" when looking at gender dynamics.

In the contribution by Chasserio et al. the interplay between women's entrepreneurial and social identity formation is richly portrayed using empirical research based on a study of 41 women entrepreneurs in France. The study provides an in-depth exploration of the dynamic processes of identity formation, identity building and identity adaptation
Emancipation and/or

oppression?

103 
IJEBR

20,2

104 to the multifaceted and multiple social and work identity categories these women embody. The paper reveals the emancipatory potentialities of entrepreneurship within the context of gender, gender identity work and resilience and expression within the social milieu of contemporary France. The paper reveals how these women's social and entrepreneurial identities do not exist on parallel tracks in neat and non-connected trajectories, but rather that they continuously interact, overlap and at times clash and create tensions. Such tensions, however, are revealed to be both emancipating and empowering at times but also inhibiting and constraining at other occasions. In this wonderfully detailed and empirically-backed paper we see demonstrated the contrary but also liberating "heretopian" dimension of entrepreneurship at play. This analysis of the diverse and everyday ways in which women continually make meaning and express their agency through the multiple selves their entrepreneurial experiences generate and challenge, exposes the inadequacy of the linear and mono-dimensional representations of the entrepreneurial stereotype as male, focused and exclusively business oriented. It also suggests, however, that a heretopian conceptualization of entrepreneurship can lead to many often unseen everyday emancipations which can enrich women's sense of self actualization and independence.

The contribution by Ozkazanc-Pan provides a fascinating postcolonial feminist analysis of aspects of the construction of entrepreneurial identities in the hightechnology industry sector. Based on a personal ethnographic account of experiences of identity formation, networking practices and socialization approaches experienced in business conference settings, Ozkazanc-Pan reveals the micro-level and paratopian processes of gender exclusion, domination and discourtesy which serves to bring young and older Turkish men into "knowing", while marginalizing Turkish women as "Others", in the potent networking spaces of Silicon Valley. Like a ritualized dance bringing some in while pushing others out, we witness the power of local context and interpersonal behaviour in binding Turkish women to fixed identity categories, while spaces for more emancipatory activities are opened up and quickly capitalized on, by the Turkish men in this study. This finely wrought paper dissects layer upon layer of the interpersonal experiences of gender and ethnicity surveillance experienced by Turkish women in such environments. It demonstrates that what may be experienced as liberating opportunities for some people, are sites of disempowerment and resistance for others. The paper is also important for its application of postcolonial feminist theory to this analysis of the minutiae of the everyday lived experiences of Turkish women being "othered" - that is, both gendered and "raced" simultaneously. Postcolonial feminist theory is used here by Ozkazanc-Pan to interrogate how hegemonic forces, rooted in the past, enable some people to gain and retain valuable contacts and networking knowledge and "let" others, such as Turkish males, into knowing while keeping Turkish women as "outsiders". The theoretical approach adopted effectively enables Ozkazanc-Pan to look into the small everyday practices by which these Turkish women's male counterparts are sequentially included into dominant culture networks and/or emancipated from the burden of past racisms. By positioning this analysis within the high tech industry sector, the paper also exposes the potency of the paratopian dimension of entrepreneurship, to accord status to some innovators while suppressing the agency of others.

Notably, whereas the first three contributions disclose the gendered nature of entrepreneurship, the next two take into consideration an aspect that, arguably, has not been studied extensively so far: entrepreneurial failure. The contribution by McCarthy et al. takes more of a "disclosing the dark side" angle, whereas the contribution by 
Olaison and Sørensen, however, traces how failure has come to be presented as something positive - discerning a "good failure" from a bad one! Both form examples of the dystopian dimension of criticality in relation to entrepreneurship we have proffered above.

McCarthy et al. aspire to broaden our understanding of the entrepreneurial landscape by examining business failure as "the other end of entrepreneurship", and more particularly the "others" at the other end: bankruptcy and insolvency professionals (IPs). The paper denaturalizes the understanding of insolvency practitioners as impartial actors who safeguard the smooth operation of the economy by disclosing how insolvency practitioners struggle to narrate their work in a coherent and unified manner, and how they appear to try out alternative narrative strategies to legitimize their work, alternating between showing sympathy and disdain for the failed (and the victims of the failed, e.g. employees and creditors). McCarthy et al. effectively reveal that, rather than "just" closing down enterprises which are no longer able to repay their debts, insolvency practitioners invoke aspirations that encourage vulnerable people into second chance entrepreneurship. To escape critique, insolvency practitioners thrust all responsibility back onto the debtor, i.e. the enterprise which went into bankruptcy, which is then seen as the locus of (failed) responsibility. In this way, insolvency practitioners can curtail the space of emancipatory action by failed entrepreneurs through individualizing failure. The exploration of the dark side in this contribution includes an observation that entrepreneurial failures foreground the (responsibility) of the individual while concealing the - immobilizing rather than emancipating - wider political economy in which the failure has taken place.

The last contribution, by Olaison and Sørensen, makes a convincing point that in today's world - even if it has become more permissible to talk about failure - not all failures can be talked about, but only those which are productive, that is, which appear to have become used, or re-framed, as a "genuine learning experience". So, it appears that it is not so much a matter of whether one fails or not, but of whether one is able or willing to use the experience of failure to perform better "next time". The fail-better movement towards which the authors point resonates with the hero myth which also does not so much deny the existence of obstacles but purports that obstacles exist precisely as rites of passage towards personal growth. As such, the paper discloses how "good" failure - that is, the capacity to reap the inherent rewards of failure for prospective business success - is rendered a defining feature of "proper" entrepreneurship, comparable to "opportunity recognition". Failure thus becomes a paradoxical secret, or what Olaison and Sørensen call the "abject" of entrepreneurship, a term owing to Julia Kristeva. It is well known that the majority of start-ups fail yet is still rare for images to be shared or understandings developed about the agony, pain and messiness which forms the actual lived experience of such failures. The authors of this paper sketch a gloomy, if thought provoking, image of entrepreneurial failure and argue that all we know about failure is an idealized representation, which serves to conceal the traumatic reality of real "failure" for so many people.

\section{Wrapping up}

Having offered a tentative conceptualization of dimensions of criticality in relation to different interpretations of emancipation as an aid for mapping existing research onto the axes of four key imagined trajectories, we concede that our attempt is necessarily ambiguous as it tends to generalize, universalize and eventually limit what might be considered "critical". In a paradoxical way we take pleasure in the thought that
Emancipation and/or oppression?

105 
IJEBR

20,2

106 prospective research will expose the limits of our "framework", by advancing approaches which cannot be nicely fitted into one or several of the four little boxes. Despite this caveat, we endorse Calas et al.'s (2009, p. 566) plea to open a space for critical entrepreneurship studies which encourages reflexive theoretical analyses and research. In line with this, our ambition in this editorial essay has been to conceptualize critical research as a process of (re)connecting the destructive/oppressive with the emancipating/empowering potential of entrepreneurship. It is precisely this process, and this "tension", which makes entrepreneurship "special” (Gasché, 2007). Our aim here has been to emphasize how the field of entrepreneurship struggles with and fights its existing limits (political, cultural, material) - and always with an eye to the invention of other possible worlds. Laclau (1996) has been used deliberately, as a cautionary reminder that entrepreneurship's emancipatory quest is anything but self-evident; it will constantly be challenged, contained and co-opted by different obstacles and forces. This dialectic movement commands our attention and we hope to see prospective research which adds both depth and subtlety to a critical understanding of how entrepreneurship contributes to the common good.

\section{References}

Ahl, H. (2004), The Scientific Reproduction of Gender Inequality; A Discourse Analysis of Research Texts on Women's Entrepreneurship, Liber AB, Malmö.

Ahl, H. (2006), "Why research on women entrepreneurs needs new directions”, Entrepreneurship Theory and Practice, Vol. 30 No. 5, pp. 595-621.

Armstrong, P. (2005), Critique of Entrepreneurship: People and Policy, Palgrave Macmillan, Basingstoke.

Calas, M.B., Smircich, L. and Bourne, K.A. (2009), "Extending the boundaries: reframing 'entrepreneurship as social change' through feminist perspectives", Academy of Management Review, Vol. 34 No. 3, pp. 552-569.

Costa, A.S.M. and Saraiva, L.A.S. (2012), "Hegemonic discourses on entrepreneurship as an ideological mechanism for the reproduction of capital”, Organization, Vol. 19 No. 5, pp. 587-614.

DeLeon, L. (1996), "Ethics and entrepreneurship”, Policy Studies Journal, Vol. 24 No. 3, pp. 495-510.

Driver, M. (2012), "An interview with Michael Porter: social entrepreneurship and the transformation of capitalism", Academy of Management Learning and Education, Vol. 11 No. 3, pp. 421-431.

Essers, C. (2009), "Reflections on the narrative approach: dilemmas of power, emotions and social location while constructing life-stories", Organization, Vol. 16 No. 2, pp. 163-181.

Essers, C. and Benschop, Y. (2007), "Enterprising identities: female entrepreneurs of Moroccan and Turkish origin in the Netherlands", Organization Studies, Vol. 28 No. 1, pp. 49-69.

Essers, C. and Benschop, Y. (2009), "Muslim businesswomen doing boundary work: the negotiation of Islam, gender and ethnicity within entrepreneurial contexts", Human Relations, Vol. 62 No. 3, pp. 403-423.

Essers, C., Benschop, Y. and Doorewaard, H. (2010), "Female ethnicity: understanding Muslim migrant businesswomen in the Netherlands", Gender, Work and Organization, Vol. 17 No. 3, pp. 320-340.

Essers, C. and Tedmanson, D. (2014) "Upsetting 'others' in the Netherlands: narratives of Muslim Turkish migrant businesswomen at the crossroads of ethnicity, gender and religion”, Gender, Work and Organization, January, doi:10.1111/gwao.12041.

Foucault, M. (1986), “Of other spaces”, Diacrits, Vol. 16 No. 1, pp. 22-27.

Gasché, R. (2007), The Honor of Thinking, Stanford University Press, Stanford. 
Goss, D., Jones, R., Betta, M. and Latham, J. (2011), "Power as practice: a micro-sociological analysis of the dynamics of emancipatory entrepreneurship", Organization Studies, Vol. 32 No. 2, pp. 211-229.

Hjorth, D. (2005), "Organizational entrepreneurship: with de Certeau on creating heterotopias (or spaces of play)", Journal of Management Inquiry, Vol. 14 No. 4, pp. 386-398.

Horkheimer, M. (1982), Critical Theory, Seabury Press, New York, NY.

Huault, I., Perret, V. and Spicer, A. (2014), "Beyond macro- and micro-emancipation: rethinking emancipation in organization studies", Organization, Vol. 21 No. 1, pp. 22-49.

James, O. (2008), The Selfish Capitalist: Origins of Affluenza, Vermilion, London.

Jameson, F. (2005), Archeologies of the Future, Verso, London.

Jones, C. and Murtola, A.-M. (2012a), "Entrepreneurship, crisis, critique", in Hjorth, D. (Ed.), Handbook of Organizational Entrepreneurship, Edward Elgar, Cheltenham, pp. 116-133.

Jones, C. and Murtola, A.-M. (2012b), "Entrepreneurship and expropriation", Organization, Vol. 19 No. 5, pp. 635-655.

Jones, C. and Spicer, A. (2009), Unmasking the Entrepreneur, Edward Elgar, Cheltenham.

Laclau, E. (1996), Emancipation(s), Verso, New York, NY.

Levitas, R. (2013), Utopia as Method: The Imaginary Reconstitution of Society, Palgrave Macmillan, New York, NY.

Ozkazanc-Pan, B. (2009), "Globalization and identity formation: a postcolonial analysis of the International entrepreneur", $\mathrm{PhD}$ thesis, University of Massachusetts-Amherst, Amherst, MA.

Parker, M. and Thomas, R. (2011), "What is a critical journal?", Organization, Vol. 18 No. 4, pp. 419-427.

Pio, E. (2005), "Knotted ends: working lives of Indian women migrants in New Zealand", Human Relations, Vol. 58 No. 10, pp. 1277-1300.

Rindova, V., Barry, D. and Ketchen, D.J. (2009), "Entrepreneuring as emancipation", Academy of Management Review, Vol. 34 No. 3, pp. 477-491.

Sarasvathy, S.D. and Venkataraman, S. (2011), "Entrepreneurship as method: open questions for an entrepreneurial future", Entrepreneurship Theory and Practice, Vol. 35 No. 1, pp. 113-135.

Spicer, A. (2012), "Critical theories of entrepreneurship", in Mole, K. and Monder, R. (Eds), Perspectives in Entrepreneurship, Palgrave Macmillan, New York, NY, pp. 149-160.

Spicer, A., Alvesson, M. and Kärreman, D. (2009), "Critical performativity: the unfinished business of critical management studies", Human Relations, Vol. 62 No. 4, pp. 537-560.

Tedmanson, D., Verduyn, K., Essers, C. and Gartner, W.B. (2012), "Critical perspectives in entrepreneurship research", Organization, Vol. 19 No. 5, pp. 531-541.

Verduyn, K. and Essers, C. (2013), "Questioning dominant entrepreneurship assumptions. The case of female ethnic minority entrepreneurs", Entrepreneurship and Regional Development, Vol. 25 Nos 7-8, pp. 612-630.

\section{Corresponding author}

Dr Karen Verduijn can be contacted at: karen.verduijn@vu.nl

To purchase reprints of this article please e-mail: reprints@emeraldinsight.com

Or visit our web site for further details: www.emeraldinsight.com/reprints
Emancipation and/or oppression? 